\title{
STRATEGIC ISSUES GROUNDWATER EXTRACTION MANAGEMENT IN RUSSIA
}

\author{
Ekaterina I. Golovina ${ }^{1}$ \\ 1 Saint-Petersburg Mining University, Vasilyevsky Island, 21 $1^{\text {st }}$ line 2, 199106, Saint-Petersburg, Russia, e-mail: \\ golova2107@mail.ru
}

Received: 2017.03.01

Accepted: 2017.04.05

Published: 2017.05.02

\begin{abstract}
Water is a key component of our environment; it is a renewable, limited and vulnerable natural resource, which provides economic, social, and environmental well-being of the population. The most promising source of drinking water supply is groundwater usage. Drinking and industrial groundwater is one of the most important components of the groundwater mineral resource base in the Russian Federation. Modern system of groundwater extraction management and state regulation is currently imperfect and has definite disadvantages, among them - lack of control over natural resources by the state, an old system of tax rates for the use of groundwater, commercialization stage of licensing, the budget deficit, which is passed on other spheres of the national economy. This article provides general information about the state of groundwater production and supply in Russia, negative trends of groundwater usage, some actions for the improvement in the system of groundwater's fund management are suggested. The most important amendments of the law "About mineral resources" are overviewed, effects of these changes are revealed and recommendations for future groundwater extraction regulation are given.
\end{abstract}

Keywords: groundwater extraction management, reserves, natural resource, water tax, license, low debit intake, the law "About mineral resources".

\section{INTRODUCTION}

Water is the most important resource and is an essential condition of life for a human being as well as a component of any production activity. Russia possesses more than $20 \%$ of global reserves of fresh water, which makes it one of the richest countries of the world from this point of view. In the long term prospective Russia is to play a special role in solving problems of rational water management, not only on its own territory but on the international arena as well. Thus, water is a strategic resource of the Russian Federation, especially due to the fact that, according to UN experts, by 2030, about half of the world's population will suffer from a lack of fresh water [Antonov, 2010].

Being a more reliable source of water supply than the surface waters the underground waters (groundwater) play a significant role in solution of water supply problems [Borevskiy et al., 2008]. First of all, groundwater presents a very specific kind of mineral resources. One of the important factors that distinguish groundwater from the other kinds of mineral resources stands for dynamic nature of reserves and resources, lower dependence of their quality on natural and anthropogenic factors, methods and volumes of production. Unlike other kinds of mineral resources, the reserves of groundwater are renewable in the process of operation [State Groundwater extraction statistics, 2013].

At the time being the Central, Volga and Siberia Federal Areas produce most of groundwater in the Russian Federation. Far East Federal Area produces the smallest amount of this precious mineral resource. Moscow region, Krasnodar Area, Kemerovo and Sverdlovsk regions 
are the leading producers of underground water. The extent of mastering of reserves (relation of groundwater production to their reserves) in Russia remains on the level of $33 \%$.

The main resources base of all the types of groundwater (fresh water, technical, mineral, thermal and industrial ones) was created due to large scale geological surveys performed for state budgetary assets before the beginning of 1990s. On average, nowadays $82 \%$ of all the amount of extracted groundwater is consumed and up to $18 \%$ of produced water is dumped without usage [State Groundwater extraction statistics, 2011].

More up-to-date provision of the territory of Russia with known reserves is shown below on the map which excludes from the total amount of reserves the deposits which are most likely not to be developed at all (Figure 1).

Predicted reserves of drinking and technical groundwater of the Russian Federation are very large; they are estimated at 869.1 million $\mathrm{m} 3 /$ day [State Groundwater extraction statistics, 2013].

According to official statistics, the share of groundwater use in overall balance of drinking water supply in Russia is 53-55\% [Borevskiy et al., 2014].

Groundwater is produced with the help of water intake structures which include various types of water supply wells, shafts, drainage facilities, capping springs [Shen, 2015]. Each groundwater intake is a complicated engineer- ing structure construction, which requires special profile preparation.

Nowadays, more than half of groundwater deposits are still not developed and remain in the non-distributed subsoil reserves fund. Most of them require re-evaluation and cannot be developed at all due to the changed economic and ecological situation (remoteness from the consumer, degree of development of the deposit territory, pollution of underground waters, non-steady chemical analysis, etc.) and higher requirements to water quality [State Groundwater extraction statistics, 2011].

The main methods of groundwater extraction management are modern system of groundwater licensing and system of groundwater production taxation [Golovina, 2015]. Analysis of the current state of groundwater usage has shown that in the new socio-economic conditions, the effectiveness of the research greatly depends not only on the degree of the hydrogeological conditions knowledge, but also on their compliance with the requirements of the regulatory framework results [Golovina, 2014].

The current mechanism for managing the extraction of groundwater resources in Russia is complex and imperfect. There is no clear delineation of roles, rights and responsibilities of organizations associated with the management of the extraction of groundwater, as well as the division of competences among them; development

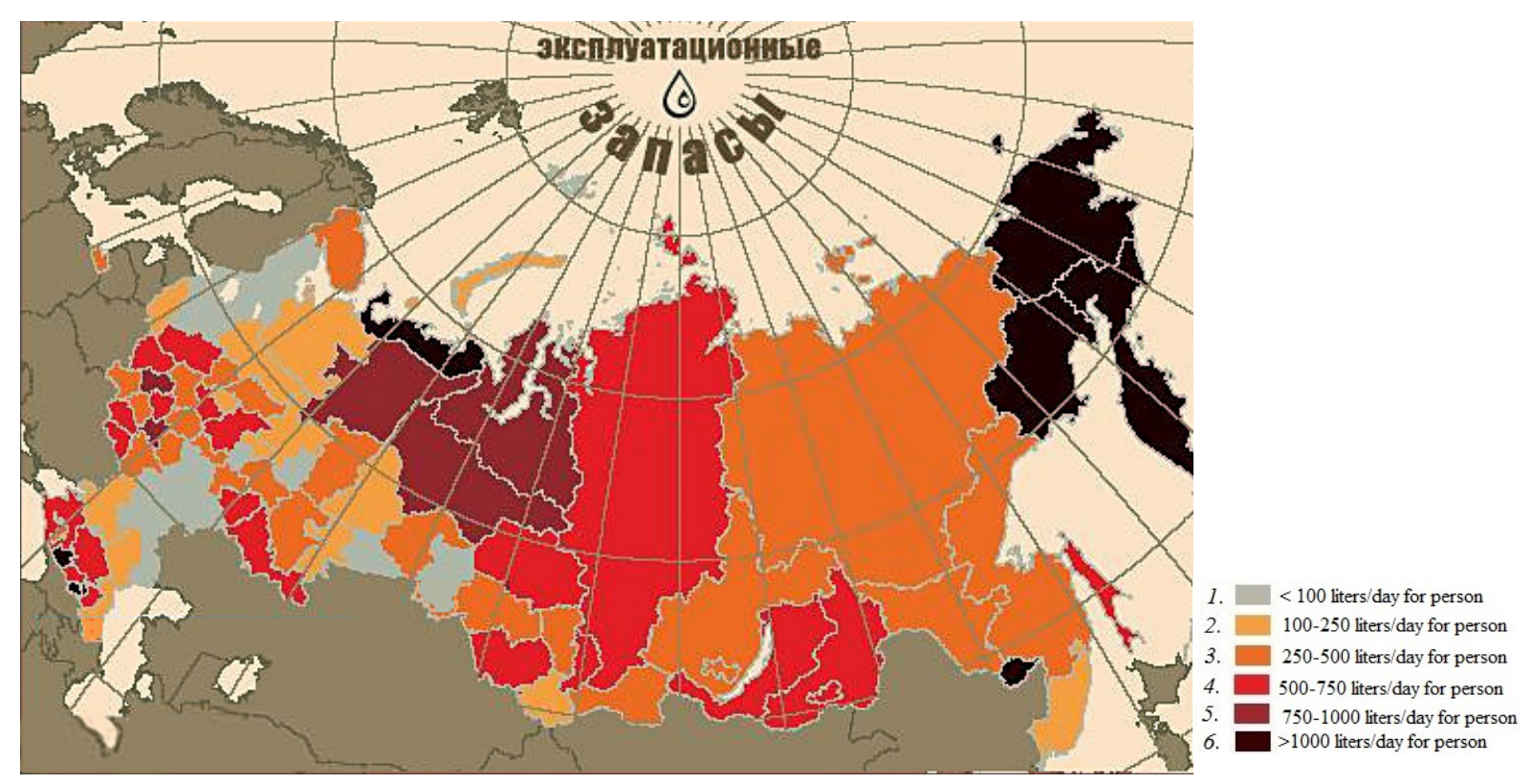

Figure 1. Provision of population of Russia with reserves of potable groundwater from deposits of the distributed and partly non-distributed fund, liters/day for one person

Source: State Groundwater extraction statistics [Electronic resource access: http://www.mineral.ru]. 
of the legislative framework; development and implementation of economic mechanisms and economic incentives of rational water use. Lack of effectiveness of the existing water management system, which is one of the main causes of the crisis state of water management, emphasize such scientists in their works as Kharitonov G.B. [2008], Isaev O.I. [2009], Prokhorova N.B. et al. [2012] and others. The need for modernization of public administration and regulation of water use, due to the growing mismatch problems in the water sector, and is also relevant at the national level [Borevskiy et al., 2014].

Groundwater extraction management should be based on a systematic approach that takes all aspects of groundwater use, starting with the proper legislative support, state regulation of its production into account.

\section{MATERIALS AND METHODS}

\section{State regulation of groundwater extraction}

Legal management of groundwater extraction features double regulation to some extent. On the one part, one can mention norms of Russian Law No. 2395-1 "About mineral resources" as of 21.02.1992. On the other part there are norms of water legislation - Water Code of Russia No. 74-FL [2007], which became valid on 01.01.2007 [Mukhina, 2011]. Besides the fact that both legal documents require updating, it is necessary to correctly separate and interrelate these two regulatory documents. At this moment there is legal lacuna, in particular in terms of taxation of utilization of groundwater objects.

The main document which regulates taxation of water objects is presented by the Tax Code of the Russian Federation, chapter 25.2 "Water tax" (introduced by Federal Law No. 83-FZ as of 28.07.2004).

In accordance with the Law of the Russian Federation "About mineral resources", geological survey and production of groundwater is realized on the basis of provided right to use the area of subsoil reserves which is executed by state permit in a form of a license [2016]. Production of appraised groundwater from the waterbearing levels by individual users is prohibited by law, which is totally wrong as it presents violation of constitutional provisions and results in forced violation of law.

\section{Latest legislative changes and their consequences}

On January $1^{\text {st }} 2015$ important changes in the law "About mineral resources" are introduced. All the amendments have a significant impact on the groundwater management system at the moment.

The first significant change in the law of the Russian Federation "About mineral resources" is a classification of subsoil areas containing groundwater used for drinking and household water supply or for water supply in industrial and agricultural purposes and whose volume of production is less than 500 cubic meters per day. Now they are lead to the areas of local authorities. Thus, now groundwater intakes, which are mined in excess of more than $500 \mathrm{~m}^{3} /$ day are administered at the federal level, and the areas with production of up to $500 \mathrm{~m}^{3}$ /day are moved to the level of the Russian Federation subjects.

Another substantial change in the same law is connected with the cancellation of the reserves estimation in areas with output of up to $100 \mathrm{cu}-$ bic meters per day. As a result, the state exempts from passing the examination of the groundwater resources of the users and thus does not bear responsibility for possible inconsistency of the quality of groundwater intakes and loses control over this mineral wealth.

According to the Russian public organization "Russian Union of hydrogeologists' (Rosgidrogeo)", such changes lead to catastrophic consequences. In particular, water intakes with capacity up to $500 \mathrm{~m}^{3} /$ day account for $95 \%$ of total intake in the whole country. Thus, the federal system of state accounting and control of groundwater intakes won't take into account $95 \%$ of groundwater intakes. In the application to the State Duma Chairman S. Naryshkin, Russian Union of hydrogeologists indicates that one of the budget loss factors they see "a reduction in tax revenues from groundwater extraction, which in conditions of chaos will not legalize the use of mineral resources, will not be accountable for the actual water intake" [2015].

Date of making changes in the law (29.12.2014) and the timing of their decision (from 01.01.2015) virtually eliminated the need to transition to a new accounting system. In this regard, many regions were not ready to assume the powers of groundwater extraction regulation. The absence of a regional legal framework was the reason for the slow adaptation to the changes made. In particular, in the North-West Federal 
District is Pskov and Novgorod Regions implemented the most rapidly, and the Leningrad region could only adopt a regulation by July 2015 . Until this time, there are regions of the Russian Federation, which are unable to adapt to the new requirements of the Ministry of Natural Resources, including St. Petersburg, where the task of managing in the public service decisionmaking on granting the right to mineral properties of local importance, containing groundwater, took over the Committee of Environmental protection and ecological safety.

The consequence of these amendments is the reserves assessment procedure. Estimation of groundwater reserves with the volume of extraction $101-500 \mathrm{~m}^{3} /$ day is carried out at the regional level, and extraction more than $501 \mathrm{~m}^{3} /$ day - on the Federal level.

A significant negative consequence of the adoption of these amendments is the establishment of the ideal conditions for uncontrolled and rapacious extraction of groundwater. Large mining companies will try to get away to the level of the local jurisdiction, where there are no controls on groundwater use today. Currently, splitting large water intakes to smaller intakes with production volumes to 100 and $500 \mathrm{~m}^{3} /$ day has begun, Reissued documents to new entities and the application forms to the local license are made. Thus, a large withdrawal is converted into a group of small separate intakes with output of up to 100 $\mathrm{m}^{3} /$ day. Consequently, groundwater extraction process becomes even more unmanageable and uncontrollable from the perspective of the state.

As before, the new legislation does not take into account the issue of registration of individual low debit intakes, the mass fraction of which is currently very high. According to the Russian law "About mineral resources" exploration and extraction of groundwater may be done only by legal bodies. The public is allowed to use only free unconfined water. Extraction of ground- water from aquifers assessed by individual users is forbidden by law, resulting in involuntary breach of the public's right to receive a quality source of drinking water.

In Table 1 information about the amount of registered garden plots in Leningrad region is shown. Approximate average volume of groundwater extraction for drinking supply was calculated by the author.

Based on the consumption of sanitary norms in the two residents on minimum standards (120 liters per person per day) calculation of groundwater extraction volume was made (for drinking water supply). In these horticultural arrays no water intake has an extraction license. The total production volume in this settlement could reach $27036 \mathrm{~m}^{3} /$ day. Underestimation of significant volumes of exploitation of aquifers adversely affects the overall balance of the groundwater resources; it often leads to a drawdown of aquifers.

\section{Lacks of the groundwater extraction management}

The current structure of groundwater resources management in Russia is complex and "formless". Such issues as structuring of the management authorities, including clear delineation of roles, rights and responsibilities in organizations, as well as the division of competences among them; preparation of the legislative framework; development and implementation of economic mechanisms and methods in economic stimulation of rational groundwater usage should be solved in the course of water management restructuring.

The main deficiencies of the modern system of groundwater extraction control are presented by such factors as:

- insufficient and not always true reporting of producing companies in front of the licensing bodies and monitoring services. This manifests itself in the absence of systems for measuring

Table 1. Information about the amount of registered garden plots in Leningrad region

\begin{tabular}{|l|c|c|}
\hline \multicolumn{2}{|c|}{$\begin{array}{c}\text { Quantity of some homesteads in garden areas of in Leningradskaya } \\
\text { region }\end{array}$} & $\begin{array}{c}\text { Calculated average volume of groundwater extraction } \\
\text { for drinking supply } \mathrm{m}^{3} / \mathrm{month}\end{array}$ \\
\hline Mshinskoye & 22500 & 162000 \\
\hline Chasha & 10000 & 72000 \\
\hline Pupishevo & 18750 & 135000 \\
\hline Babino & 6000 & 43200 \\
\hline Novaya Ropsha & 35000 & 252000 \\
\hline Dunai & 13500 & 97200 \\
\hline Novinka & 6900 & 49680 \\
\hline
\end{tabular}


levels of water in the wells and lack of information on change of chemical composition of underground water, etc. [Yazvin, 2015];

- absence and low precision of operation of measuring equipment which results in lower indications during production of water [Yazvin, 2003];

- shortage and sometimes even the absence of the system of surveillance wells, which does not make it possible to perform surveys and analyses of drawdown of groundwater reserves (due to the absence of financing);

- availability of large number of old deserted water intake facilities and creation of a whole network of private water intakes that cannot be controlled and accounted for (complicated and expensive procedure of licensing of water intakes results in massive license-free subsoil use);

- absence and violation of sanitary protection zones of the acting water intake facilities which resulted from abrupt increase of price for land within the recent 10 to 15 years;

- low rate of water tax which does not stimulate rational use of underground waters. For instance, very precious by their type potable underground waters can be extensively used for technical and technological needs;

- total prohibition for production of potable groundwater by private entities for their own needs (in case of no possibility to connect to the system of centralized water supply due to remoteness of objects), which results in a construction of individual water intake facilities without any permits. This trend is also defined by massive construction of individual houses and settlements on the former agricultural fields and in forest lands.

Thus, the overall picture of the volumes of groundwater extraction in the whole regions becomes very unclear and inaccurate. The law "on mineral resources" allows making water intake without a license only from the first from the surface water bearing level which is not a source of central water supply, but this criterion can be evaluated only by a specialist hydrogeologist.

Attraction of private capital in a form of investment programs to the sector of water supply for the population which will result in higher rates for water supply but will not resolve the problem of reasonable water use on the scale of the whole regions as operation of any water intake well impacts work of neighboring water intakes, and vice versa.

Any changes in the system of state regulation of groundwater fund in Russia are impossible without improving the economic aspects of groundwater use, namely pricing and taxation system of groundwater extraction. Current imperfect taxation system objectively counteracts the intensive reproduction of mineral resource base, integrated and rational use of groundwater. Finally, the collection of groundwater tax does not provide even the current expenses of the state for monitoring and exploration. Therefore, it is necessary to propose a new system of taxation, which depends on various parameters. Collection of groundwater tax should provide a self sufficiency for groundwater extraction branch and bring it from the category of the subsidized sectors in the national economy.

\section{RESULTS AND DISCUSSION}

State regulation of groundwater production and consumption for various domestic purposes requires immediate reform and total reconsideration for some positions. First of all, water as a mineral resource must be considered as state property belonging to the whole nation. And, consequently, production of underground water, distribution of funds by regions, target assignment, etc. must be performed under control of state specialized organizations and tax bodies and with restructuring of underlying laws (the law "on mineral resources", Water Code).

The main aspects of reform may be reduced to the following items:

1) It is necessary to reconsider basic taxation legislation (taxes for water) in the part of evaluation of price characteristics of underground water as mineral resource.

Nowadays, groundwater tax rate is rather negligible (9 kopecks for $1 \mathrm{~m}^{3}$ of water) and does not depend on the quality of water itself and on its amount (target use, except for separate kinds of healthcare and recreation use). Low tax rate does not allow forming the budget for financing water intakes operation control systems, there is not enough assets for performance of planned and perspective geological survey works, large scale ecological and monitoring programs. 
Alongside with that, low tax rate for groundwater production forms attitude to such a deficit mineral resource as to some almost free inexhaustible raw material.

Calculation of new tax rates is a complicated and multifactor task which requires profound economic analysis. But, the main issue remains to be the price of underground water which is defined by the following factors:

- quality of water (availability of useful and detrimental microcomponents),

- amount of reserves,

- target use,

- market price,

- social components,

- possibility of sales on domestic markets,

- remoteness of deposit from the consumer,

- difficulty of production (net cost),

- hydrogeological factors (peculiarities).

2) Groundwater production and survey licensing system is based on the principle of registration and permission. The list of licensing requirements includes the whole package of projects, reports, approvals. Requirements for licensing (though clear and specific) are not simple for execution. In some cases, it takes years to obtain a license for production of underground water.

It would be reasonable to organize a united body of state registration (licensing) which would perform the functions of a "customer" that is pro- duction of regulation works as per requirements of the license on the principles of involvement of tender contractor specialized organizations (Figure 2). Thus, control over licensed works will be simplified and the price of the package of license documents will be financed.

3) The most important factor of field reforming stands for the need of registration, licensing and tax registration of all the single and group groundwater intakes. Such intakes include low debit wells, shafts, capping springs. Each of such objects must receive geological and ecological passport and must be licensed in accordance with the simplified program. Reporting system must be implemented for each of the intakes.

Involvement of this segment of groundwater reserves users in the united data base will make it possible to obtain priceless hydrogeological and ecological information and, on the other hand, will refill the field budget via the taxation system. Financing of geological survey field at the expenses of consumers will make it possible to increase the level of survey of new deposits of underground waters, to maintain already developed water sources, to perform reevaluation of reserves and improve ecological component.

The problem of groundwater resources development is not only connected with the subjects of the Russian Federation, it also has respect to the bordering states. The proposed

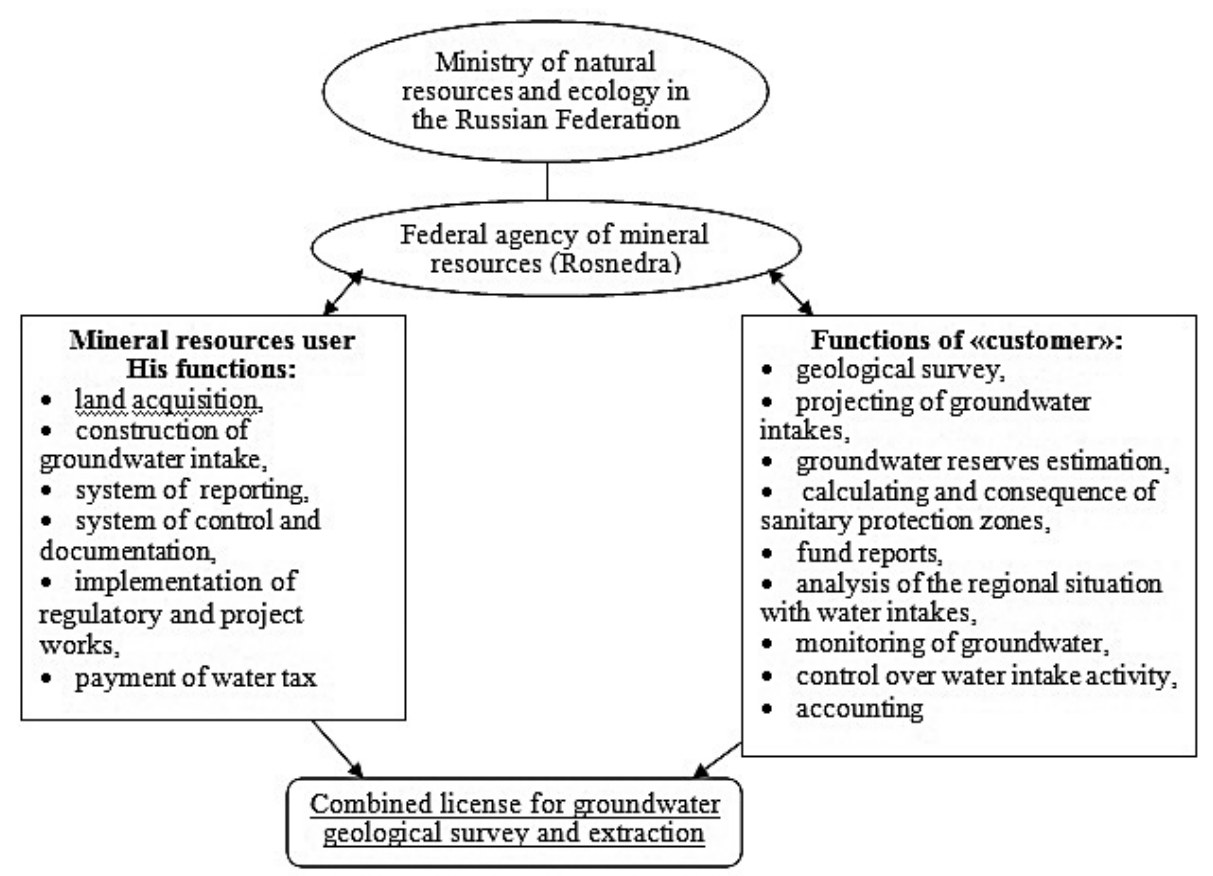

Figure 2. Suggested scheme of state groundwater extraction regulation 
measures require international expertise and deep economic analysis.

\section{Possible solutions of the problem}

After analyzing latest legislative changes in groundwater extraction management some ways and improving principles can be given:

1) Sectoral pay-back.

It can be reached at the expense of tax revenues at the extraction (production) of groundwater, license fees, which should cover the cost of the federal and regional budgets for the activities of control, monitoring, and various exploration targets and environmental programs. Extraction of groundwater should not be unprofitable for the state budget.

2) The integrity of the production structure of groundwater management

Effective management is possible only if we have one parent body with the ability to receive and process information, to plan and control the activities of extracting underground water. The vector of the regulatory framework is clear - the detailed regulation of activities of groundwater users and officials responsible for the performance of public functions.

Nowadays less attention is paid to the content of the materials, which negatively affects the quality and efficiency of geological exploration of groundwater and, in particular, as a whole. Monitoring requirements is not carried out by groundwater users in the proper amount, as they are not used for operational management, and an effective mechanism of influence on them is absent.

3) The principle of development

Exploration work for groundwater should be attractive investment field of activity. A balance between the interests of the state as the owner of this social and strategic mineral wealth and groundwater users, receiving required water resources should be kept. Any deposit of groundwater before its development takes a certain cycle of exploration work, which is currently costly. Consequently, both the state and private mining companies are trying to reduce the amount of exploration to the detriment of the quality of information received. When you create a single extraction of groundwater exploration task management system can be optimized, and free funds to invest in exploration using innovative technolo- gies not only in the stages of field work, but also in modern numerical information processing systems, such as software and algorithmic complex GeoCODE.

4) Creation of clear tariff policy

If the state has a clear, precise and regulated system of taxation and license fees (fixed payments) and the sphere of tariff regulation can be normalized. In the cost of groundwater extraction additional work associated with geological study, licensing requirements, etc. are not included.

5) The validity of the tax policy

The system of taxation groundwater extraction should address not only the officially registered intakes, but also the private sector (individual water users) that today do not have the possibility to register their withdrawals and pay water tax.

6) The principle of responsibility

Tax and license fees will increase the comprehensive responsibility of groundwater to the state, and vice versa. In the first case, the groundwater user is obliged to pay for the right to use (production) of minerals owned by the State, in the form of taxes and license activities aimed at safe environmental and geological points of view of extracting fossil. In the second - the state, according to the collected budget should provide the necessary resource potential of the groundwater user in the declared quantity and quality for the period of the settlement operation.

7) The economic development of the industry The principle is based on the increase in the proportion of the population to ensure quality of service and drinking water from underground sources, as the underground water have a number of advantages over surface waters (security required mineral composition, water intake location close to the consumer, etc.)

8) Budgeting

Planning the financing of certain geological and environmental programs is only possible upon receipt of budget payments (taxes and royalties) by region, taking into account the share of cash collections. Regions that maximize tax revenues, respectively, require the most attention from the geological and environmental services (environmental safety, drawdown of water - etc.). At the same time, it is necessary to take into account those regions where there is an increase in development areas such as the 
Far East, Primorsky Region, etc. In these areas exploration works, the search for new deposits of underground water are necessary.

9) The scale of the problem

Groundwater is located practically across the country (from Kaliningrad to Kamchatka). There are no analogues of such minerals in size, reserves and importance. Therefore, the government should pay special attention to this issue (along with hydrocarbon resources).

\section{CONCLUSION}

Since Russia has rich resources of fresh underground waters, one of the major practical problems in their fund managing is a rational use of its resources and protection of aquifers from contamination and depletion. Economic instruments in the structure of state groundwater extraction management are the system of taxation, system of licensing, state regulation and control over groundwater production. Legal regulation of groundwater extraction is very important not only for current situation, but also for future actions.

It is worth noting that the legislative reform requires large-scale adjustments. The consequence of the amendments is inevitably a budget shortfall of tax revenues, license fees, respectively, the federal target programs will be reduced.

There are many constructive suggestions from the leading Russian experts in the field of groundwater extraction in the area of state administration and regulation, but so far they have not found its realization in the new legislation. In this connection, it is expedient to create a wide expert group of specialists in the field of the national economy to solve the problems in structuring groundwater management in Russia.

The problem of development of groundwater resources is not only connected with the subjects of the Russian Federation, it also has references to the bordering states. The proposed measures require international expertise and deep economic analysis [Aquilar, 2011].

\section{Acknowledgments}

This paper was reviewed by first pro-rector, Dr of Economic sciences, Professor Natalia Pashkevich at Mining University, Saint-Petersburg, Russia and vice director of Saint-Petersburg fil- ial in Federal Budget-funded entity "State commission of mineral reserves", expert Galina Smelova. This work was supported by the grant of the government of Saint-Petersburg (Committee of Science and Higher Education), diploma and reference № 16002 .

\section{REFERENCES}

1. Aguilar, D. 2011. Groundwater Reform in India: An Equity and Sustainability Dilemma. URL: http://www.tilj.org/content/journal/46/ num3/Aguilar623.pdf

2. Antonov, A. 2010. Water is new oil. URL: http:// inosmi.ru/economic/20101024/163785871.html.

3. Application of the Union of hydrogeologists № $016 / 2015$ from 25.02.2015 to the Chairman of the State Duma S. Naryshkin.

4. Borevskiy, B.V., L.S. Yazvin, and S.L. Pugach. 2008. Underground water: the state of provision of potable and technical water. Mineral resources in Russia. Economics and Management, Vol. 4.

5. Borevskiy, B.V., M.M. Charepansky, and A.L. Yazvin. 2014. Expert assessments of the resource potential of groundwater in the development of schemes at complex use and protection of water resources. Exploration and Conservation of Mineral Resources, Vol. 5, 29-32.

6. Golovina, E.I. 2014. Economic mechanism of rational groundwater usage. Proceedings of the Samara Scientific Center of the Russian Academy of Sciences, 16, 1(4), 951-955.

7. Golovina, E.I. 2015. Perfection of organization and economic mechanism of groundwater rational use. Abstract, PhD thesis, Saint-Petersburg, p. 4.

8. Isaev, O.I. 2009. Using economic assessment of water resources in water management. Abstract, PhD thesis, Moscow, p. 7.

9. Kharitonov, G.B. 2008. Perfection of the organizational-economic mechanism for implementing the state water policy in the Russian Federation, Abstract, PhD thesis, Rostov-on-Don, p. 4

10. Mukhina, E.M. 2011. Legal regulation of groundwater use and protection. Abstract, Phd thesis, Moscow, p. 4.

11. Prokhorova, N.B., K.V. Krutikova, and Y.B. Merzlikina. 2012. Control water management complex of Russia: state of implementation functions to the actual achievement of the goals of water policies. Ekaterinburg, p. 192.

12. Shen, D. 2015. Groundwater management in China. Water Policy, Vol. 17, 61-82.

13. State Groundwater extraction statistics, 2011. 
URL: http://www.mineral.ru/Facts/russia/131/291/ index.html.

14. State Groundwater extraction statistics, 2013. URL: http://www.mineral.ru/Facts/russia/161/540/3 26 water.pdf.

15. The law of the Russian Federation "About mineral resources" 21.02.1992 N 2395-1. Latest revision 03.07.2016.

16. The Tax Code of the Russian Federation, chapter 25.2 "Water tax" (introduced by Federal Law No. 83-FZ as of 28.07.2004). URL: https://www. nalog.ru/html/sites/www. eng.nalog.ru/Tax $\% 20$ Code\%20Part\%20Two.pdf
17. Water code of the Russian Federation 03.06.2006 N74-FL (is active from 01.01.2007). URL: http:// www.cabri-volga.org/DOC/PolicyRoundtable/WaterCodeOfRF-UnofficialEnglish Translation.pdf

18. Yazvin, A.L. 2015. Scientific substantiation of information support system of geological exploration resource potential fresh groundwater. Abstract. Doctor. geol.-min. science. Thesis, Moscow, p. 3.

19. Yazvin, L.S. 2003. Evaluation of probable resources of underground drinking water and provision of the Russian population in groundwater for domestic, drinking water supply. Exploration and Protection of Mineral Resources, Vol. 1, 13-22. 